Original Research Paper

\title{
Fractional Reserve Banking and Price Stability: Evidence from Gulf Cooperation Council (GCC) Countries
}

\author{
${ }^{1}$ Osman Sayid Hassan Musse, ${ }^{2}$ Abdelghani Echchabi and ${ }^{3}$ Hassanuddeen Abdul Aziz \\ ${ }^{I}$ Faculty of Economics and Muamalat, Islamic Science University of Malaysia, \\ Bandar Baru Nilai, 71800 Nilai, Negeri Sembilan, Malaysyia \\ ${ }^{2,3}$ College of Business, Effat University, Jeddah 22332, Saudi Arabia
}

Article history

Received: 16-7-2015

Revised: 25-7-2015

Accepted: 6-8-2015

Corresponding Author: Abdelghani Echchabi

College of Business, Effat

University, Jeddah 22332,

Saudi Arabia

Email: abdelghani.mo@gmail.com

\begin{abstract}
This study aims at investigating the possible influence of the current money creation process applied by the commercial banks through the fractional reserve system on the overall prices stability in the Gulf Cooperation Council (GCC) countries. The study uses yearly data spanning from 2008 through 2013 for Qatar, Kuwait, Oman, Saudi Arabia and United Arab Emirates and applies panel regression analysis based on the pooled data set. The results indicate that neither outstanding deposits nor outstanding loans have a significant influence on general price levels.
\end{abstract}

Keywords: Debt Creation, Fractional Reserve, Inflation, GCC

\section{Introduction}

Under both monetary systems-commodity backed money and paper money, the primary objective of monetary policy is to maintain price stability for goods and services and to have a stable value for money in all economic periods. This is to protect the savings and avoid exchange rate volatility and the un-stability in general price level and most importantly to retain public confidence in local currencies.

In this regard, there are a number of tools to uphold the value of the money as a stable currency and to tackle the increasing inflation rate. Quantity control is one of the successful policies to control money quantity. As a consequence, any change in the quantity of money will lead either to inflation or deflation in the economy. The increase in the quantity of money often will be due to printing additional banknotes by central banks or issuing loans by commercial banks through fractional reserve system (Federal Reserve Bank of Chicago, 1994). In other words, one of the advantages of price stability is that it encourages savings and hence, provides more room for a much better distribution of funds. Therefore, price stability is a widely sought goal as the appropriate objective of monetary policy and today, it becomes one of the primary considerations of central banks around the world (Kadušić et al., 2011).

In addition, in this modern economy, new money is created when commercial banks attempt to extend a credit to their borrowers and investors with the assistance of fractional reserve mechanism. This process is called debt creation in the form of bank loans.

For instance, in the case United Kingdom, private banks create $97 \%$ of the money in circulation in the form of loans, while the bank of England issues only 3\% of the money, which is in the form of banknotes. This is particularly true in a society, where the access of credit/debit cards, internet banking and mobile banking is high. This newly created money is only existing in the form of electronic/digital/accounting entries in banks' computes, but, it does not exist in the form of cash (Ryan-Collins et al., 2014).

As a result, this newly created money increases money growth rate and subsequently reduces the purchasing power of the currency and leads to high inflation as well as wealth transfer form the largest group of the society to the smallest group (Meera, 2004).

Besides that, Stoop and Sornette (2010) concluded that credit creation fuels economic bubbles, making the system unstable and leading economies into crises. This is in the line with general belief about the monetary theory, which predicts that there is a strong long-run correlation between money growth and inflation in the economy (Frain, 2004).

By definition, fractional reserve is the modern banking practice in which, private banks have to keep a small fraction of the amount deposited in reserve for the future withdrawers and lend out the remainder for borrowers. It will be decided based on a country's central bank policies. 
For example, in the case of Malaysia, fractional reserve requirement is $2 \%$ of the total amount deposited, implying that commercial banks are required to keep only two percent for every amount deposited in their respective banks and they have a right to lend out the remaining $98 \%$ to loan seekers, resulting in an increase in money supply, which is known to be the main source of inflation and instability in prices in the current economic system (Meera and Larbani, 2006). In the case of the United States of America the requirement is $3 \%$, while $1.5 \%$ for the United Kingdom.

Accordingly, the current study attempts to examine the above claim i.e., the influence of the current practice of money creation by the commercial banks on the inflation in the GCC countries. The money creation process in the banking system is measured with both outstanding deposits and loans of the commercial banks.

The remaining part of this paper is organised as follows: The second section discusses the concept of money and debt creation and its relationship with inflation and the following section briefly describes the data used and results obtained. The final section discusses the conclusions and implications of the research findings.

\section{Literature Review}

Credit creation plays vital role in this modern economy in terms of financing economic activities such as trade, agriculture, investments and personal financing i.e., home, car financing (Hasan, 2008). Generally, debt creation occurs when commercial banks in the present monetary system issue loans to their borrowers and investors. In doing so, they are causing changes to the equilibrium of money supply level, disrupting the balance between the supply and demand for goods and services while influencing the interest rate relative (Call and Cochran, 2000).

On the other hand, inflation is due to excessive money creation that was originated either by private or central banks (Madurapperuma, 2007). It is defined as an increase in general price level of goods and services. There are many theories to elaborate the relationship between money supply, money demand and inflation. The most popular among them is the Quantity Theory of Money (Yue and Leung, 2011). Based on this theory, debt creation is the root cause of inflation and economic illness in the present economic system.

In the empirical literature, the relationship between the money supply and inflation has received much attention from researchers. For instant, Frain (2004) studied the relationship between money growth and inflation applying coefficient model with sample of multicountry data set. The author found that there is strong correlation between average growth rates of money and average inflation rates. Moreover, this correlation remains strong even when countries with higher average inflation rates are removed from the sample size.

For the same purpose, Chimobi and Uche (2010) investigated the relationship between money, inflation and output in the context of Nigeria employing the cointegration and Granger-causality test with annual data for the period of 1970-2005. They concluded that there is no cointegration between money supply and inflation; however, money supply was found to be the cause for both output and inflation under Granger test.

Using the same method as Chimobi and Uche (2010), Simwaka et al. (2012) examined the relationship between money supply and inflation in the context of Malawi and ended up with same conclusion of Chimobi and Uche (2010) in the case of Nigeria stating that the increase of money supply is the main cause for inflation in Malawian case.

In his study, Lozano (2008) attempted to examine the links between budget deficit, money growth and inflation in the context of Colombia, but with a different method employed in the above studies, namely, vector error correction model with quarterly based data that covers the period of 25 years. However, he ended with a similar result that indicates close relationship between inflation and money growth as well as between money growth and fiscal deficit.

With the same variables; money growth and inflation, but in the context of Sri Lanka, Madurapperuma (2007) studied factors behind inflation concluding that the current inflation is due to the expansion of money supply in the country's economy.

In a more comprehensive analysis, the causality test was used to examine the relationship between budget deficit, monetary mass and inflation in three transition economies i.e., Albania, Romania and Bulgaria reporting that budget deficit has expanded money supply in the above three countries, it has tended to depreciate the exchange rate and it has leaded to inflation rate volatility. In other words, the study figured out that public financing through issuing bonds is the main cause for the increase of money supply and then inflation rate volatility in the case of Albania, Bulgaria and Romania (Milo, 2012).

On the other hand, Kwon et al. (2006) examined a sample of 71 countries with 42 periods from 1963 to 2004) employing panel data analysis. They found that the average annual growth of money exceeded the average inflation growth about 4 per cent during the study period and testing debt growth and inflation rate; therefore they concluded that the debt growth is significantly associated with high inflation in high debt countries than in low debt countries. 
Overall, the major difference between this study and the above few studies is centred on variables that were used in the analysis. Specifically, the authors investigated the relationship between debt growth and inflation growth, while the above studies examined the relationship between money supply growth and inflation rate. Both approaches have concluded that money growth/debt growth is the primary cause of inflation in the economy and in this modern economy money is equal to debt.

With a similarity in the variables emphasised, Metin (1998) examined the relationship between budget deficit and inflation for Turkish economy using multivariate cointegration as a tool for analysis ending up with a conclusion that budget deficit is significantly affecting the inflation level in Turkey.

On the other hand, for the same purpose, but focusing on price stability and inflation rate correlations, Kadušić et al. (2011) studied inflation and price stability in case of Yugoslavia. They concluded that high inflation rate may cause long lasting damage to the whole economy, while a failure to regulate the supply of money leads to destroy the value of money and causes price instability for goods and service.

To investigate the relation between money creation through fractional reserve practices and price stability in the context of MENA countries, Musse et al. (2014) examined the influence of money creation on the price stability using yearly based data from 2005 to 2011 and applying panel regression analysis based on the pooled data set with a result that neither outstanding deposits nor outstanding loans do have a significant influence on inflation.

In a nutshell, the above studies are in line with the general monetary theories, which indicates that there is a strong relationship between money supply and inflation rate except Musse et al. (2014) study, which contradicted with general prediction of monetary theory. Therefore, this study tends to investigate the effect of debt creation in the commercial banking system on price stability and inflation rate and particularly, it attempts to examine the monetary practices with the general belief of the monetary theory.

\section{Methodology}

The study uses three main variables, namely, outstanding deposits, outstanding loans and inflation for Qatar, Kuwait, Oman, Saudi Arabia and United Arab Emirates. These countries were selected based on data availability, this is what justifies the exclusion of Bahrain. The data spans from 2008 through 2013, for all the mentioned countries. The data were obtained from the World Bank and International Monetary Fund (IMF) databases. Accordingly, the model can be written as follows:
Infl $=+\beta_{1} L+$

Infl $=+\beta_{1}$ Dep +

Based on the above model, the following hypotheses were established:

- H1: The amount of outstanding loans has a positive influence on the inflation rates in GCC countries.

- H2: The amount of outstanding deposits has a positive influence on the inflation rates in GCC countries.

In order to test the above hypotheses, the study uses panel regression analysis. For this matter, the analysis estimates the Pooled Ordinary Least Square (POLS) model and subsequently uses the Breusch-Pagan Lagrangian Multiplier (LM) test to verify the suitability of POLS for this model.

\section{Findings}

Table 1 summarises selected parameters of the used variable. Specifically, the table shows a mean of 52.21 for the outstanding deposits, 55.22 for loans and 4.12 for the inflation levels. Similarly, the series recorded standard deviation of 21.5 for outstanding deposits, 19.74 for loans and 4.33 for inflation. The Skewness and Kurtosis figures indicate that the series are slightly positively skewed, however, this did not have a significant impact on their normality distribution as shown by the probability values of the Jarque-Bera test. Hence, generally the data appears to be adequate for further analyses.

Further, Table 2 presents the correlation between the three variables of the study. Mainly the high correlation between the outstanding deposits and loans is relatively high. This demonstrates the current practice of money creation by commercial banks through debt multiplication and fractional reserve banking (Meera and Larbani, 2006). In addition, inflation is negatively correlated with both deposits and loans. Nevertheless, the correlation is relatively negligible.

In order to test the above claims and initial results, the study formulated two main hypotheses. The latter suggest that both outstanding loans (H1) and deposits (H2) have a significant positive impact on inflation. These hypotheses were tested through panel ordinary least square and are reported in Tables 3 and 4.

In this regard, the results indicate that outstanding loans do not have an impact on inflation. Hence, hypothesis 1 is not supported. Similarly, the findings revealed that outstanding deposits do not have an impact on inflation. Hence, hypothesis 2 is neither supported. This is in line with Musse et al. (2014). This implies that the fractional reserve system does not necessarily promote inflation, especially if it is not abused by the dominating parties. 
Table 1. Descriptive analysis

\begin{tabular}{llll}
\hline & Deposits & Loans & Inflation \\
\hline Mean & 52.21032 & 55.22816 & 4.129318 \\
Median & 47.27689 & 47.45675 & 3.203396 \\
Maximum & 99.43831 & 102.7010 & 15.05015 \\
Minimum & 25.82108 & 34.11969 & -4.863278 \\
Std. Dev. & 21.50095 & 19.74673 & 4.336916 \\
Skewness & 0.918928 & 1.113289 & 0.709244 \\
Kurtosis & 2.839119 & 2.937108 & 3.599920 \\
Jarque-Bera & 4.112681 & 5.995276 & 2.866184 \\
Probability & 0.127921 & 0.049905 & 0.238570 \\
\hline
\end{tabular}

Table 2. Correlation matrix

\begin{tabular}{llll}
\hline & Deposits & Loans & Inflation \\
\hline Deposits & 1 & 0.90 & -0.25 \\
Loans & 0.90 & 1 & -0.21 \\
Inflation & -0.25 & -0.21 & 1 \\
\hline
\end{tabular}

Table 3. Panel least squares

\begin{tabular}{lllll}
\hline Variable & Coefficient & Std. Error & t-Statistic & Prob. \\
\hline C & 6.768158 & 2.414957 & 2.802600 & 0.0093 \\
Loans & -0.047781 & 0.041255 & -1.158183 & 0.2569 \\
\hline
\end{tabular}

Table 4. Panel least squares

\begin{tabular}{lllll}
\hline Variable & Coefficient & Std. Error & t-Statistic & Prob. \\
\hline C & 6.807494 & 2.114503 & 3.219430 & 0.0033 \\
Deposits & -0.051296 & 0.037543 & -1.366342 & 0.1831 \\
\hline
\end{tabular}

Hence, it can be concluded that the money creation through debt does not have any influence on the inflation variation across the GCC countries.

\section{Discussion}

The main purpose of this study was to examine the possible influence of the current commercial banks' money creation process on the price stability in the case of GCC countries. The results clearly showed that neither outstanding deposits nor loans have significant influence on the inflation levels in these countries.

This finding has significant implications for the theory, the policy makers as well as to the practitioners. In this regard, the findings are inconsistent with the contemporary economics and finance theory claiming that the process of money creation practiced by the commercial banks influences the inflation levels in the economy and contributes to price instability, particularly in the case of selected GCC countries. This indicates that the process of money creation has been thoroughly managed by the authorities in these countries b considering the totality of the macroeconomic indicators. Particularly, the inflation rates were closely monitored to remain within a level acceptable by the authorities in these countries. Which might explain the above findings. This has also contributed to the stability of the exchange rate of the GCC currencies, as well as their interest rates.
Furthermore, these findings imply that this form of money, i.e., fiat money, just like other kinds of money, can be used as medium of exchange as long as it is not abused by the issuing authorities and/or speculators. Hence, beside the nature of money itself, the community's behaviour is what can help achieving the underlying purpose of money. Thus, an important criterion for selecting an "alternative money" would be the extent to which the latter can be abused and manipulated by different parties. This is particularly relevant to Islamic banking and finance, whereby there were recently many attempts to develop alternative currencies as the basis for the Islamic banking and finance transactions.

\section{Conclusion}

Though the current study has significant contributions, it still has some limitations that need to be addressed in the future studies in this area. The main limitation of the study is the use of data for seven years only and for 5 GCC countries only. Hence, future studies are required to extend the study by including larger number of countries and for a longer periods of time. Similarly, the future studies are recommended to include other macro-economic variables for a more comprehensive analysis.

\section{Acknowledgment}

The authors would like to thank the anonmous reviewers as well as the associate editor for their efforts and valuable feedback.

\section{Funding Information}

The authors have no support or funding to report.

\section{Author's Contributions}

Osman Said Hassan Musse: Problem formulation and literation review.

Abdelghani Echchabi: Problem identification, data collection and analysis.

Hassanuddeen Abdul Aziz: Theoretical underpinings and implicatiions.

\section{Ethics}

This article is original and contains unpublished material. The corresponding author confirms that all of the other authors have read and approved the manuscript and no ethical issues involved.

\section{References}

Federal Reserve Bank of Chicago, 1994. Modern Money Mechanics: A Workbook on Bank Reserves and Deposit Expansion. CreateSpace Independent Publishing Platform, ISBN-10: 1453645578, pp: 42. 
Call, S.T. and J.P. Cochran, 2000. Free banking and credit creation: Implications for business cycle theory. Quarterly J. Austrian Economics, 3: 35-50.

Chimobi, O.P. and U.C. Uche, 2010. Money, price and output: A causality test for Nigeria. Am. J. Sci. Res., 8: 78-87.

Frain, J.C., 2004. Inflation and money growth: Evidence from a multi-country data-set. Economic Soc. Rev., 35: 251-266.

Hasan, Z., 2008. Credit creation and control: an unresolved issue in Islamic banking. Int. J. Islamic Middle Eastern Finance Manag., 1: 69-81.

Kadušić, S.E., P. Bojović and A.Z. Gee, 2011. Critical analysis of inflation and price stability in monetary policy. Proceedings of the International Conference on Financial Management and Economics (FME' 11), IACSIT Press, Singapore, pp: 284-290.

Kwon, G., L. McFarlane and W. Robinson, 2006. Public Debt, Money Supply and Inflation: A Cross-Country Study and its Application to Jamaica.

Lozano, I., 2008. Budget deficit, money growth and inflation: Evidence from the Colombian Case.

durapperuma, A., 2007. Money, inflation and growth a review of the concepts and past relationships. 19th Anniversary Convention, Seylan Bank PLC, Sri Lanka, pp: 59-92.

Meera, A.K., 2004. The theft of nations: Returning to Gold. Kuala Lumpur: Paperback.

Meera, A.K.M. and M. Larbani, 2006. Seigniorage of fiat money and the Maqasid al Shari'ah: The unattainabless of maqasid. Humanomics, 2: 84-97.
Metin, K., 1998. The relationship between inflation and the budget deficit in Turkey. J. Bus. Economic Statist., 16: 412-422.

DOI: $10.1080 / 07350015.1998 .10524781$

Milo, P., 2012. The impact of the budget deficit on the currency and inflation in the transition economies. J. Central Bank. Theory Practice, 1: 25-57.

Musse, O.S., H.A. Aziz and A. Echchabi, 2014. The effect of banks' debt creation on price stability: Evidence from middle east and North Africa. Middle East J. Manage., 1: 224-231. DOI: 10.1504/MEJM.2014.060530

Ryan-Collins, J., T. Greenham, R. Werner and A. Jackson, 2014. Where Does Money Come From? A Guide to the UK Monetary and Banking System. 2nd Edn., New Economics Foundation, London, ISBN-10: 1908506547, pp: 186.

Simwaka, K., P. Ligoya, G., Kabango and M. Chikonda, 2012. Money supply and inflation in Malawi: An econometric investigation. Int. J. Applied Economics Finance, 6: 74-88.

Stoop, M. and D. Sornette, 2010. Credit creation and its contribution to financial crises. MSc Thesis, Department of Management, Technology and Economics, Swiss Federal institute of Technology Zurich, Zurich.

Yue, H.Y. and K.T. Leung, 2011. The effects of quantitative easing on inflation rate: A possible explanation on the phenomenon. Eur. J. Economics Finance Administrative Sci., 41: 34-40. 